\title{
REVISITING THERAPEUTIC SULFONAMIDES IN THE ATTEMPT TO IMPROVE THE ANTIMICROBIAL PROPERTIES THROUGH METAL-ION COORDINATION
}

\author{
TAMARA TOPALĂ ${ }^{\#}$, ANDREEA ELENA BODOKI ${ }^{\# *}$, ADRIANA HANGAN, SÎNZIANA \\ GHEORGHE-CETEAN, LUMINIȚA OPREAN
}

"Iuliu Hațieganu” University of Medicine and Pharmacy, Faculty of Pharmacy, Department of General and Inorganic Chemistry, 12 Ion Creangă Street, 400010, Cluj-Napoca, Romania

*corresponding author: bota@umfcluj.ro

${ }^{\#}$ Authors with equal contribution.

\begin{abstract}
The serious health issues raised by microbial resistance to first-line and last-resort antibiotics have triggered the search for efficient strategies to prevent and treat infections. Metal coordination of structures with antibacterial properties represents a promising approach in improving and refining the biological activity of both antibiotics and metal ions as it provides the opportunity to design compounds with unique and tunable features. Sulfonamides in particular are an interesting choice since they combine the structural characteristics required for both antibacterial activity and metal coordination. The present paper reviews the reports on the antimicrobial properties of complexes of metal ions coordinating sulfonamides widely used in the therapy of infections over the past decades.
\end{abstract}

\section{Rezumat}

Identificarea unor soluții fezabile care să rezolve problema rezistenței la antibiotice rămâne o provocare continuă pentru cercetători, determinând de-a lungul timpului dezvoltarea unor strategii eficiente de prevenție și tratare a infecțiilor bacteriene. Obținerea unor compuși prin coordinarea ionilor metalici cu liganzi ce prezintă activitate antibacteriană consacrată reprezintă o abordare promițătoare privind proiectarea de noi compuşi mai eficienți din punct de vedere al acțiunii antimicrobiene. În acest sens, sulfonamidele reprezintă o alegere interesantă deoarece combină caracteristicile structurale necesare atât pentru activitatea antibacteriană cât și pentru funcționarea lor ca liganzi în chimia coordinativă. Lucrarea de față aduce informații actuale privind proprietățile antimicrobiene ale complecșilor metalici ai unor sulfonamide utilizate pe scară largă în ultimele decenii în tratarea infecțiilor bacteriene.

Keywords: sulfonamides, metal complexes, antibacterial activity

\section{Introduction}

The discovery of antimicrobial compounds is a turning point in modern medicine. The introduction in therapy in the 1930s of the first sulfonamide (prontosil, a prodrug sulfanilamide), followed shortly by the introduction of penicillin, resulted in a drastic decrease of the morbidity and mortality caused by bacterial infections. Currently however, the misuse and overuse of antibiotics, the use of invasive medical procedures and extensive surgery, and the increase of immunecompromised patients are listed among the main causes of microbial resistance to first-line and last-resort antibiotics [26]. The 2018 World Health Organization's report on antibiotic resistance reveals high levels of resistance to a number of serious bacterial infections caused by Escherichia coli (E. coli), Klebsiella pneumoniae (K. pneumoniae), Staphylococcus aureus (S. aureus), Streptococcus pneumoniae (S. pneumoniae), Salmonella spp. and Mycobacterium tuberculosis (M. tuberculosis). Moreover, biofilm production characteristic for pathogens such as $S$. aureus and Pseudomonas aeruginosa ( $P$. aeruginosa) plays a crucial role in the virulence of the bacteria and in the persistence of chronic infections. Within this ecosystem with particular features such as primitive homeostasis, a primitive circulatory system, and metabolic cooperativity [18], bacteria survive exposure to concentrations of antibiotics up to 1000 -fold greater than those lethal for free bacterial cells [48]. It is wide world accepted that the ability to treat infections relies nowadays on efficient strategies to prevent infections, to limit drug and multi drug resistance and to develop new effective antibiotics. One valid strategy could be the metal ion coordination of structures with known and well characterized antibacterial activity. The present paper aims to support a proof of concept, which is the possibility to improve and refine the antibacterial activity of therapeutical sulfonamides upon coordination with diverse metal ions. 
Historically, the first agents with antibacterial properties were metal compounds; their wide use dates back hundreds of years and gradually decreased, only when organic antibiotics came into play in the $20^{\text {th }}$ century. The renewed interest in metal-based antimicrobials reflects the hopes that less microbial resistance will develop [31, 53].

Domagk's report (1932) on the protective effects of prontosil against murine streptococcal infections triggered the rapid development of numerous sulfonamides widely used in therapy: sulfapyrine against pneumonia, sulfacetamide against urinary infections, succinoylsulfathiazole against gastrointestinal infections, sulfathiazole to treat wound infections [41, 42]. Nowadays, sulfonamides are seldom used as monotherapy because of their limited spectrum and fast developing drug-resistance.

The bacteriostatic properties of sulfonamides derive from their structural analogy and their competitive interference with the para-aminobenzoic acid in the synthesis of tetrahydrofolic acid (an essential growth factor for bacteria) by the dihydropteroate synthase $[41,49,50]$. The ionic species formed as a result of the deprotonation of the sulfonamide moiety is, in fact, the bioactive compound, but its limited lipid solubility prevents efficient penetration across the bacterial membrane. It has been suggested that it is the unionized form of the sulfonamide that actually penetrates the cellular membrane and that ionization occurs within the bacterial cell [24, 27].
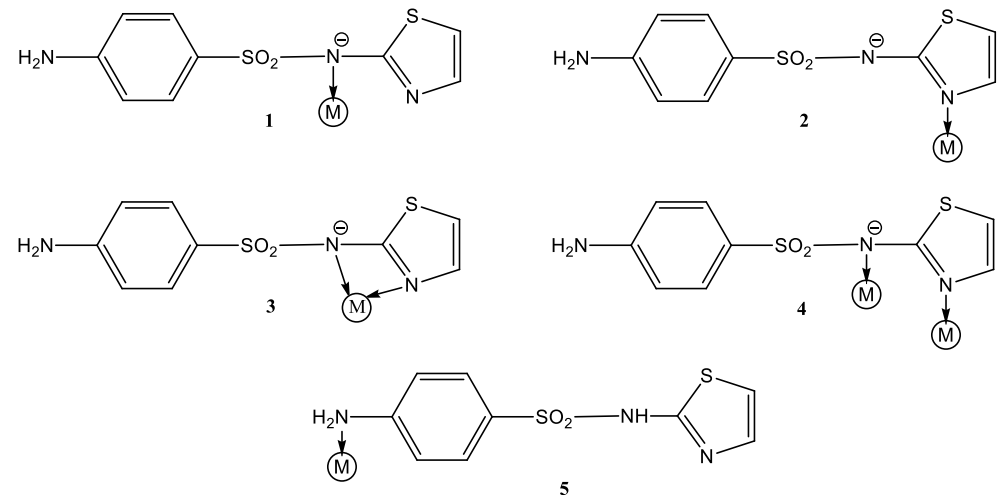

Figure 1.

Coordination modes of sulfonamides exemplified for sulfathiazole

In this context, sulfonamides have attracted increasing attention since they combine the features required for both antibacterial activity and metal ion coordination. It has been observed that sulfonamides can coordinate metal ions in several different ways $[4,6,9,52]$, in most cases as a consequence of the deprotonation of the N-sulfonamidic atom. The most frequent coordination modes are exemplified for sulfathiazole,

\section{Metal-ion coordination}

Coordination to metal ions has been proven to be a valid and promising strategy to improve and enhance the antimicrobial activity of both organic drugs and metal ions. Coordination compounds take advantage of the complementarities between the properties of the metal ion and of the ligand. They provide the opportunity to exploit the unique properties of metal centres, such as: multiple oxidation states, redox properties, a wide variety of coordination numbers, symmetries and structural patterns, which offer highly adaptable platforms for drug design [20, 58]; at the same time, the ligands may be pharmacologically active, or they may play a key role in transport, target recognition or interaction. Moreover, as it is the case of many metallodrugs within biological media, the complex may undergo ligand substitution and/or redox reactions with beneficial effects on the antibacterial activity [47].

Thus, aiming to develop complexes with antimicrobial properties researchers have revisited old antibiotic molecules or synthesized analogues, derivatives or completely new molecules that can coordinate metal ions $[9,42,54,59]$. Some authors argue however that the relationship between chelation and bacterial toxicity is very complex and, as it is expected to be a function of steric, electronic and pharmacokinetic factors, the antibacterial activity may actually be hindered upon metal coordination [3, 32, 46]. It is the case for instance of the reported $\mathrm{Cu}$ (II) ternary complexes with sulfathiazole and cephalosporin ligands [3], or the case of the $\mathrm{Ru}(\mathrm{III})$ and $\mathrm{Pt}(\mathrm{II})$ complexes of sulfamethazine [32]. 
40], but they can also appear as bridging two metal ions (mode 4) $[12,15]$. The amino group in the para position (mode 5) may be also involved in metal-ion coordination $[11,13,14]$. Since the amino group is essential for the antimicrobial activity of the sulfonamide, it is however desired to remain non-coordinated.

\section{Sulfonamide-containing metal complexes with antibacterial properties}

For numerous reported metal complexes, the antibacterial activity is higher than that of the free parent sulfonamide but there are scarce data regarding mechanistic studies, or the detailed structure of the complexes that could lead to pertinent conclusions regarding a structure-activity relationship. The following section focuses on those studies that conclude on mechanistic aspects such as identification of the bioactive entity, evaluation of lipophilicity or synergistic action of metal ions and free ligands and does not aim to be an exhausting inventory of metal-based antimicrobials. The table lists those complexes with antibacterial activity superior to that of the free parent compound and/or to the activity of a relevant standard. Early studies brought evidence of the higher antimicrobial activity of the coordinated species with respect to the free sulfonamides for complexes such as $\mathrm{Ag}(\mathrm{I})$-sulfadiazine, $\mathrm{Cu}(\mathrm{II})$-sulfacetamide or $\mathrm{Cu}(\mathrm{II})$ sulfamethoxazole complex $[5,30]$. In some cases the biological activity of the sulfonamide based metal complexes differs completely from that of the free ligand. It is the case of the non-steroidal antiinflammatory drug nimesulid, a structure bearing a sulfonamide moiety without antibacterial properties. $\mathrm{Cu}$ (II) or $\mathrm{Ag}(\mathrm{I})$ complexes of nimesulid (i.e. $\left[\mathrm{Cu}(\mathrm{NMS})_{2}\right.$ (bipy)] and $[\mathrm{Ag}(\mathrm{NMS})]$, respectively) were reported to exert antibacterial activity against both Gram-positive ( $S$. aureus) and Gram-negative ( $E$. coli, $P$. aeruginosa) bacteria. For $[\mathrm{Ag}(\mathrm{NMS})]$ the antibacterial activity was similar to that of $\mathrm{AgNO}_{3}$ and gentamicin against the tested strains [7, 19].

The $\operatorname{Ag}(\mathrm{I})$-sulfadiazine complex (Silvazine $^{\mathrm{TM}}$, Flamazine $^{\mathrm{TM}}$, Acticoat ${ }^{\mathrm{TM}}$ ) is probably the best-known example of the success of the metal-ion coordination strategy (as depicted in Figure 2). This complex has been proven to be an effective topical antimicrobial agent employed in burn therapy, effective on Grampositive and Gram-negative bacteria including $P$. aeruginosa, one of the bacteria most often incriminated in recurrent wound infections. It is worth mentioning however that the antibacterial activity of the majority of the $\operatorname{Ag}(\mathrm{I})$ complexes with sulfonamides, including $\mathrm{Ag}(\mathrm{I})$-sulfadiazine, appears to be actually linked to the presence of the $\operatorname{Ag}(\mathrm{I})$ ions that are slowly released from the complex, whereas the ligand's role is mainly that of a carrier. The ligand's presence also prevents $\operatorname{Ag}(\mathrm{I})$ precipitation with chlorides and the subsequent hypochloraemia in burns [23]. The fast release of
$\mathrm{Ag}(\mathrm{I})$ ions from the inorganic salt limits the use of $\mathrm{AgNO}_{3}$ in therapy, since $\mathrm{Ag}(\mathrm{I})$ concentrations higher than $1 \%$ exhibit tisular toxicity $[17,23,25]$.<smiles>Nc1ccc(S(=O)(=O)N=C2N=CC=[N+]2O)cc1</smiles>

Figure 2.

Structure of $\operatorname{Ag}(\mathrm{I})$-sulfadiazine complex

Several other $\operatorname{Ag}(\mathrm{I})$ complexes with sulfonamides (sulfamethizole, sulfisoxazole, sulfadimethoxine, sulfamethoxydiazine, sulfachloropyridazine) exhibit minimum inhibitory concentrations (MIC) similar or higher than those observed for $\mathrm{AgNO}_{3}$, and they have interesting features that allow for the slow release of the bioactive $\operatorname{Ag}(\mathrm{I})$ ions $[22,37,38,57]$. On the other hand, the results reported by Velluti et al. for the $\operatorname{Ag}(\mathrm{I})$ complexes of sulfamoxole showed that the antibacterial activity of the coordinated compounds against $P$. aeruginosa is not due to the synergism of the free components, but rather to new active species resulting from the coordination process. Moreover, the authors suggest that despite the low solubility and suboptimal lipophilicity, the observed microbiological activity on Gram-negative and Gram-positive bacteria and fungi (Table I) relies on the nanometric size of the complexes [55].

Several studies concluded that the chelation process translates into an increase of the hydrophobicity and lipophilicity and therefore favours the penetration of the metal complexes through the lipid layer of the cell membrane $[2,16,30]$. Upon chelation, the ligand's polarity will be reduced due to the overlap of the ligands' orbitals and the metal-ligand charge transfer. Furthermore, the chelation process increases the delocalization of the $\pi$ electrons over the whole chelate ring and this translates into an increase in the lipophilicity of the metal complex [45]. The comparative study reported by Kremer et al. [30] on the lipophilicity and antimicrobial activity of a series of $\mathrm{Cu}(\mathrm{II})$ complexes with sulfisoxazole, sulfamethoxazole, sulfamethizole, sulfadiazine, sulfamerazine, sulfapyridine, sulfachloropyridazine, sulfamethoxypyridazine concluded that lipophilicity generally increased upon $\mathrm{Cu}(\mathrm{II})$ coordination. All complexes were active against $S$. aureus and $E$. coli but, interestingly, the complexes with sulfonamides bearing five-membered heterocycles as $\mathrm{N}$-substituents (i.e. isoxazole, diazomethizole) were more efficient than the free parent compounds, whereas the complexes with six-membered rings substituents (i.e. heteropyrimidine, pyridine, pyridazine) were less efficient 
than the uncoordinated antibiotic. In the group of ligands with a five-membered heterocycle substituent, all sulfonamides coordinate through the heterocyclic $\mathrm{N}$ atom, whereas in case of the ligands with a sixmembered heterocycle the coordination is suggested to occur through a different donor moiety (e.g. the phenylamino group) which is required to remain free for the antimicrobial activity [56]. Moreover, coordination through the heterocyclic $\mathrm{N}$ atom decreases the electron density on the sulfonamide $\mathrm{N}$ atom favouring the bioactive anionic form of the sulfonamide [30]. Another study on a Ni(II) complex with sulfisoxazole supported the results obtained in case of the $\mathrm{Cu}$ (II) analogue and pointed out the role of the metal ion for the antibacterial activity. $\left.[\mathrm{Ni} \text { (sulfisoxazole })_{2}\left(\mathrm{H}_{2} \mathrm{O}\right)_{4}\right] \cdot 2 \mathrm{H}_{2} \mathrm{O}$ and the free sulfisoxazole presented equal $\mathrm{MIC}$, while the isostructural $\left.[\mathrm{Cu} \text { (sulfisoxazole })_{2}\left(\mathrm{H}_{2} \mathrm{O}\right)_{4}\right] \cdot 2 \mathrm{H}_{2} \mathrm{O}$ was four-fold more active than the free sulfonamide. It was suggested that coordination to $\mathrm{Cu}$ (II) favours the penetration into the cell where the complex releases the anionic active form of the sulfonamide presumably due to the $\mathrm{Cu}$ (II) reduction [44]. In case of the $\mathrm{Ni}(\mathrm{II})$ complex either the transport of the complex through the membrane or the liberation of the sulfonamide species inside the cell is not achieved $[36,51]$.

Boughougal et al. [10] recently reported a $\mathrm{Zn}$ (II) ternary mononuclear complex that associates in two antibiotics the coordination environment, enrofloxacin and sulfadiazine, $[\mathrm{Zn}(\mathrm{LH})(\mathrm{Erx})(\mathrm{ErxH})] \mathrm{ClO}_{4}$ (Table I). The antibacterial efficiency of the complex was tested against E. coli, S. aureus and E. faecalis and compared to that of the $\mathrm{Zn}(\mathrm{II}), \mathrm{Co}(\mathrm{II}), \mathrm{Cu}(\mathrm{II})$ and $\mathrm{Ni}(\mathrm{II})$ binary complexes of enrofloxacin or sulfadiazine. The results are noteworthy since the antibacterial efficiency was found to be between 2 and 20 times higher than the efficiency of both the free antibiotics and of the metal complexes bearing only one of the two antibiotics as ligands. Although the mechanism and the role of the metal centre are not clear, it appears that the synergetic effect of entities within the complex (two different antibiotics and the metal centre with antiseptic properties) drastically increases the antibacterial activity of the ternary complex. Moreover, it was suggested that the interaction and transfer through the lipoidal membrane are favoured by the positive charge of the cationic complex. In contrast, the ternary $\mathrm{Cu}$ (II) complexes associating sulfathiazole and a series of cephalosporins (cefazolin, cefalotin, cefotaxime and ceftriaxone) reported by Anacona et al. did not prove to be characterized by the same synergetic effect; their antibacterial activity was comparable to that of the free cephalosporin [3].

The antibacterial activity of ternary complexes of $\operatorname{Ag}(\mathrm{I})$ and $\mathrm{Au}(\mathrm{I})$ with sulfonamides and phosphine derivatives, respectively (Table I), was reported with interesting results $[1,2,33-35]$. The study of the $\mathrm{Au}(\mathrm{I})$ monomer complex and $\mathrm{Ag}(\mathrm{I})$ polymeric complex with sulfamethoxazole reported by Marques et al. concluded that these complexes exhibited significant antibacterial properties against $E$. coli, $S$. aureus and P. aeruginosa. $\left[\mathrm{Ph}_{3} \mathrm{PAu}(\mathrm{SMTZ})\right]$ was 256 times more active than a 5:1 mixture of sulfamethoxazole and trimethoprim against $S$. aureus, and 64 times more active than the free sulfamethoxazole against $E$. coli. $[\mathrm{Ag}(\mathrm{SMTZ})]_{\mathrm{n}}$ was 32 times more active than the uncoordinated sulfonamide on $P$. aeruginosa [33]. The $\mathrm{Au}(\mathrm{I})$ complex of sulfathiazole and triphenylphosphine and its analogue bearing sulfamethoxazole and triphenylphosphine as ligands showed in vitro activity against $M$. tuberculosis and their effects were potentiated by the combination with trimethoprim (Table I) [2]. More recently, the same research group extended the study and tested the $\operatorname{Ag}(\mathrm{I})$ and $\mathrm{Au}(\mathrm{I})$ binary and ternary complexes against rapidly growing mycobacteria, M. fortuitum, M. abscessus, M. massiliense (Table I). The results showed that several complexes of sulfadiazine and sulfamethoxazole (Table I) were significantly more active than the free sulfamethoxazole, one of the antimicrobial agents of choice for the treatment of mycobacteriosis. The metal complexes showed bactericidal activity and synergistic effect when combined to trimethoprim against $M$. abscessus and, in addition, acted faster than the free sulfamethoxazole [1]. The study reported by Mizdal et al. confirmed that sulfadiazine $\mathrm{Au}-\mathrm{PPh}_{3}$, sulfamethoxazole $\mathrm{Au}-\mathrm{PPh}_{3}$, sulfadiazine $\mathrm{Ph}_{2} \mathrm{P}-\mathrm{Au}-\mathrm{Au}-\mathrm{PPh}_{2}$, and sulfamethoxazole $\mathrm{Ph}_{2} \mathrm{P}-\mathrm{Au}-\mathrm{Au}-\mathrm{PPh}_{2}$, were more active against $\mathrm{S}$. aureus and $P$. aeruginosa that the free sulfamethoxazole, and, in addition, induced a reduction in the metabolic activity and biofilm formation for the tested strains [34, 35].

The $\mathrm{Cu}(\mathrm{II})$ complex of sulfathiazole and diethylenetriamine, $\left[\mathrm{Cu}(\mathrm{stz})_{2}(\right.$ dien $\left.)\right] \cdot 3 \mathrm{H}_{2} \mathrm{O}$ was found to exhibit a very effective antimicrobial activity, especially against Gram-negative bacteria and fungi (MIC values in the range $1-4 \mu \mathrm{g} / \mathrm{mL}$ ); for instance, the antimicrobial activity of the complex against $P$. aeruginosa, E. coli and $A$. niger increased at least 256-fold in comparison with the activity of the free sulfathiazole [39], as presented in Table I.

The results obtained by A. Di Santo et al. on a Mn(II) complex of sulfamethoxazole, $\left[\mathrm{Mn}\left(\mathrm{H}_{2} \mathrm{O}\right)_{6}\right]_{0.5}\left[\mathrm{Mn}(\mathrm{SMX})_{3}\right]$, suggest an effect of the complex on the mechanism involved in biofilm formation, i.e. quorum sensing, more than antibiotic properties. It was suggested that the anti-biofilm properties of the complex could be explained in terms of the positive charge of $\mathrm{Mn}$ (II) aquacation that might increase its sorption to typically negatively charged biofilms [21]. 
Table I

Sulfonamide-containing metal complexes with antibacterial properties

\begin{tabular}{|c|c|c|c|}
\hline Compound & \begin{tabular}{|c|} 
MIC for complex (MIC \\
for free sulfonamide or \\
MIC for chosen standard)
\end{tabular} & Remarks & Reference \\
\hline \multicolumn{4}{|c|}{ Sulfadiazine complexes } \\
\hline$\left[\begin{array}{c}{[\mathrm{Zn}(\mathrm{LH})(\mathrm{Erx})(\mathrm{ErxH})] \mathrm{ClO}_{4}} \\
-\end{array}\right.$ & $\begin{array}{l}\text { E. coli: }<0.5 \mathrm{mg} / \mathrm{L} \\
\quad(128 \mathrm{mg} / \mathrm{L}), \\
\text { S. aureus: }<0.5 \mathrm{mg} / \mathrm{L} \\
\quad(8 \mathrm{mg} / \mathrm{L}), \\
\text { E. faecalis: }<0.5 \mathrm{mg} / \mathrm{L} \\
\quad(>256 \mathrm{mg} / \mathrm{L})\end{array}$ & $\begin{array}{l}\text { Complex more active than the } \\
\mathrm{Zn}(\mathrm{II}), \mathrm{Co}(\mathrm{II}), \mathrm{Ni}(\mathrm{II}) \text { or } \mathrm{Cu}(\mathrm{II}) \\
\text { binary complexes with Erx or } \\
\text { sulfadiazine. }\end{array}$ & [10] \\
\hline $\begin{array}{c}\text { Sulfadiazine } \mathrm{Au}-\mathrm{PPh}_{3} \\
\text { Note: detailed structure not available }\end{array}$ & $\begin{array}{l}\text { M. fortuitum: } 19.53 \mu \mathrm{g} / \mathrm{mL} \\
\text { MRSA: } 2 \mu \mathrm{g} / \mathrm{mL}\end{array}$ & \begin{tabular}{|c|} 
Synergism when associated with \\
trimethoprim against $M$. abscessus. \\
Antibiofilm properties against \\
MRSA. No data available for free \\
sulfadiazine; complex more active \\
than the reference sulfamethoxazole \\
- M. fortuitum: $32 \mathrm{mg} / \mathrm{L}$ \\
MRSA: $256 \mathrm{mg} / \mathrm{L}$
\end{tabular} & {$[1,34]$} \\
\hline $\begin{array}{c}\text { Sulfadiazine } \mathrm{Ph}_{2} \mathrm{P}-\mathrm{Au}-\mathrm{Au}-\mathrm{PPh}_{2} \\
\text { Note: detailed structure not available }\end{array}$ & $\begin{array}{l}\text { M. fortuitum: } 19.53 \mu \mathrm{g} / \mathrm{mL} \\
\text { M. massiliense: } 9.76 \mu \mathrm{g} / \mathrm{mL}, \\
\quad \text { MRSA: } 8 \mu \mathrm{g} / \mathrm{mL}\end{array}$ & \begin{tabular}{|} 
No data available for free \\
sulfadiazine; complex more active \\
than the reference sulfamethoxazole \\
- M. fortuitum: $32 \mathrm{mg} / \mathrm{L}$, \\
M. massiliense: $64 \mathrm{mg} / \mathrm{L}$, \\
MRSA: $256 \mathrm{mg} / \mathrm{L}$. \\
Synergism when associated with \\
trimethoprim against $M$. abscessus; \\
Anti-biofilm properties against \\
MRSA.
\end{tabular} & {$[1,34]$} \\
\hline \multicolumn{4}{|c|}{ Sulfamethizole complexes } \\
\hline$[\mathrm{Cu}(\mathrm{S})$ & \begin{tabular}{|c|} 
S. aureus: $3.20 \mathrm{mmol} / \mathrm{L}$ \\
$(9.25 \mathrm{mmol} / \mathrm{L})$ \\
E. coli: $3.20 \mathrm{mmol} / \mathrm{L}$ \\
$(9.25 \mathrm{mmol} / \mathrm{L})$ \\
P. aeruginosa: $1.60 \mathrm{mmol} / \mathrm{L}$ \\
$(9.25 \mathrm{mmol} / \mathrm{L})$
\end{tabular} & & [57] \\
\hline $\begin{array}{c}{[\mathrm{Ag}(\mathrm{SMZ})]} \\
\text { Note: detailed structure not available }\end{array}$ & \begin{tabular}{|c|} 
S. aureus: $3.31 \mathrm{mmol} / \mathrm{L}$ \\
E. coli: $0.83 \mathrm{mmol} / \mathrm{L}$ \\
P. aeruginosa: $0.41 \mathrm{mmol} / \mathrm{L}$
\end{tabular} & $\begin{array}{c}{[\mathrm{Ag}(\mathrm{SMZ})] \text { is less active than } \mathrm{AgNO}_{3} \cdot} \\
\text { The free sulfonamide does not present } \\
\text { inhibitory activity under the tested } \\
\text { concentrations and conditions. }\end{array}$ & {$[57]$} \\
\hline \multicolumn{4}{|c|}{ Sulfamethoxazole complexes } \\
\hline $\int \|_{0}^{S-N} \backslash_{A g}^{N}$ & \begin{tabular}{|c|} 
E. coli: $64 \mu \mathrm{g} / \mathrm{mL}$ \\
$(512 \mu \mathrm{g} / \mathrm{mL})$, \\
S. aureus: $64 \mu \mathrm{g} / \mathrm{mL}$ \\
$(>512 \mu \mathrm{g} / \mathrm{mL})$, \\
P. aeruginosa: $16 \mu \mathrm{g} / \mathrm{mL}$ \\
$(512 \mu \mathrm{g} / \mathrm{mL})$,
\end{tabular} & & [33] \\
\hline & M. smegmatis: $0.305 \mu \mathrm{g} / \mathrm{mL}$ & $\begin{array}{l}\text { No data available for free sulfa- } \\
\text { methoxazole; complex more active } \\
\text { than the reference trimethoprim } \\
\text { - M. smegmatis: } 4.88 \mu \mathrm{g} / \mathrm{mL}\end{array}$ & [2] \\
\hline & $\begin{array}{l}\text { M. massiliense: } 9.76 \mu \mathrm{g} / \mathrm{mL} \\
(64 \mu \mathrm{g} / \mathrm{mL})\end{array}$ & $\begin{array}{l}\text { Synergism when associated with } \\
\text { trimethoprim against } M \text {. abscessus. }\end{array}$ & [1] \\
\hline
\end{tabular}


FARMACIA, 2019, Vol. 67, 5

\begin{tabular}{|c|c|c|c|}
\hline Compound & \begin{tabular}{|c|} 
MIC for complex (MIC \\
for free sulfonamide or \\
MIC for chosen standard) \\
\end{tabular} & Remarks & Reference \\
\hline \multirow[t]{4}{*}[\mathrm{Ph}_{3}\mathrm{PAu}(\mathrm{SMTZ})]{} & \begin{tabular}{|c|} 
E. coli: $8 \mu \mathrm{g} / \mathrm{mL}$ \\
$(512 \mu \mathrm{g} / \mathrm{mL})$, \\
S. aureus: $2 \mu \mathrm{g} / \mathrm{mL}$ \\
$(>512 \mu \mathrm{g} / \mathrm{mL})$, \\
P. aeruginosa: $256 \mu \mathrm{g} / \mathrm{mL}$ \\
$(512 \mu \mathrm{g} / \mathrm{mL})$, \\
\end{tabular} & & [33] \\
\hline & $\begin{array}{c}\text { MRSA: } 2 \mu \mathrm{g} / \mathrm{mL} \\
(256 \mu \mathrm{g} / \mathrm{mL})\end{array}$ & $\begin{array}{l}\text { Anti-biofilm properties against } \\
\text { MRSA. }\end{array}$ & [34] \\
\hline & \begin{tabular}{|l|} 
M. massiliense: $19.53 \mu \mathrm{g} / \mathrm{mL}$ \\
$(64 \mu \mathrm{g} / \mathrm{mL})$.
\end{tabular} & & [1] \\
\hline & M. smegmatis: $2.44 \mu \mathrm{g} / \mathrm{mL}$ & $\begin{array}{c}\text { No data available for free sulfa- } \\
\text { methoxazole; complex more active } \\
\text { than the reference trimethoprim } \\
\text { - M. smegmatis: } 4.88 \mu \mathrm{g} / \mathrm{mL} \text {. } \\
\text { Additive effect when associated } \\
\text { with trimethoprim against } M \text {. } \\
\text { smegmatis and synergy when } \\
\text { associated with trimethoprim } \\
\text { against } M \text {. abscessus. }\end{array}$ & [2] \\
\hline $\begin{array}{l}\text { Sulfamethoxazole } \mathrm{Ph}_{2} \mathrm{P}-\mathrm{Au}-\mathrm{Au}-\mathrm{PPh}_{2} \\
\text { Note: detailed structure not available }\end{array}$ & \begin{tabular}{|c|} 
M. massiliense: $19.53 \mu \mathrm{g} / \mathrm{mL}$ \\
$(64 \mu \mathrm{g} / \mathrm{mL})$, \\
MRSA: $8 \mu \mathrm{g} / \mathrm{mL}$ \\
$(256 \mu \mathrm{g} / \mathrm{mL})$
\end{tabular} & $\begin{array}{c}\text { Synergy when associated with } \\
\text { trimethoprim against } M \text {. abscessus; } \\
\text { Anti-biofilm properties against } \\
\text { MRSA. }\end{array}$ & {$[1,34]$} \\
\hline $\begin{array}{c}\text { Sulfamethoxazole } \mathrm{Au} \\
\text { Note: detailed structure not available }\end{array}$ & $\begin{array}{c}\text { M. fortuitum: } 19.53 \mu \mathrm{g} / \mathrm{mL} \\
(32 \mu \mathrm{g} / \mathrm{mL}), \\
\text { M. abscessus: } 4.88 \mu \mathrm{g} / \mathrm{mL} \\
\quad(8 \mu \mathrm{g} / \mathrm{mL}) \\
\text { M. massiliense: } 9.76 \mu \mathrm{g} / \mathrm{mL} \\
(64 \mu \mathrm{g} / \mathrm{mL})\end{array}$ & $\begin{array}{l}\text { Synergism when associated with } \\
\text { trimethoprim against } M \text {. abscessus. }\end{array}$ & [1] \\
\hline $\begin{array}{c}{\left[\mathrm{Cu}(\mathrm{SMTZ})_{2}\left(\mathrm{H}_{2} \mathrm{O}\right)_{4}\right] \cdot 3 \mathrm{H}_{2} \mathrm{O}} \\
\text { Note: detailed structure not available }\end{array}$ & \begin{tabular}{|c|} 
S. aureus: $4 \mu \mathrm{g} / \mathrm{mL}$ \\
$(16 \mu \mathrm{g} / \mathrm{mL})$ \\
E. coli: $4 \mu \mathrm{g} / \mathrm{mL}$ \\
$(128 \mu \mathrm{g} / \mathrm{mL})$ \\
\end{tabular} & & [30] \\
\hline $\begin{array}{c}\text { Sulfamethoxazole } \mathrm{Cu} \\
\text { Note: detailed structure not available }\end{array}$ & \begin{tabular}{|c|} 
M. fortuitum: $9.76 \mu \mathrm{g} / \mathrm{mL}$ \\
$(32 \mu \mathrm{g} / \mathrm{mL})$, \\
M. massiliense: $19.53 \mu \mathrm{g} / \mathrm{mL}$ \\
$(64 \mu \mathrm{g} / \mathrm{mL})$
\end{tabular} & $\begin{array}{c}\text { Synergy when associated with } \\
\text { trimethoprim against } M \text {. abscessus. }\end{array}$ & [1] \\
\hline $\begin{array}{c}\text { Sulfamethoxazole Cd } \\
\text { Note: detailed structure not available }\end{array}$ & $\begin{array}{l}\text { M. fortuitum: } 19.53 \mu \mathrm{g} / \mathrm{mL} \\
\quad(32 \mu \mathrm{g} / \mathrm{mL}) \\
\text { M. abscessus: } 4.88 \mu \mathrm{g} / \mathrm{mL} \\
(8 \mu \mathrm{g} / \mathrm{mL}), \\
\text { M. massiliense: } 4.88 \mu \mathrm{g} / \mathrm{mL} \\
(64 \mu \mathrm{g} / \mathrm{mL})\end{array}$ & $\begin{array}{c}\text { Synergy when associated with } \\
\text { trimethoprim against } M \text {. abscessus. }\end{array}$ & [1] \\
\hline $\begin{array}{c}\text { Sulfamethoxazole } \mathrm{Hg} \\
\text { Note: detailed structure not available }\end{array}$ & \begin{tabular}{|l|} 
M. fortuitum: $9.76 \mu \mathrm{g} / \mathrm{mL}$ \\
$(32 \mu \mathrm{g} / \mathrm{mL})$ \\
M. abscessus: $4.88 \mu \mathrm{g} / \mathrm{mL}$ \\
$(8 \mu \mathrm{g} / \mathrm{mL})$, \\
M. massiliense: $4.88 \mu \mathrm{g} / \mathrm{mL}$ \\
$(64 \mu \mathrm{g} / \mathrm{mL})$
\end{tabular} & $\begin{array}{c}\text { Synergy when associated with } \\
\text { trimethoprim against } M \text {. abscessus. }\end{array}$ & [1] \\
\hline \multicolumn{4}{|c|}{ Sulfathiazole complexes } \\
\hline $\begin{array}{c}{\left[\mathrm{Au}(\mathrm{STZ})\left(\mathrm{PPh}_{3}\right)\right]} \\
\text { Note: detailed structure not available }\end{array}$ & \begin{tabular}{|c|} 
M. smegmatis: $4.88 \mu \mathrm{g} / \mathrm{mL}$ \\
$(4.88 \mu \mathrm{g} / \mathrm{mL})$
\end{tabular} & $\begin{array}{l}\text { Synergism when associated with } \\
\text { trimethoprim against } M \text {. smegmatis. }\end{array}$ & [2] \\
\hline$\left[\mathrm{Cu}(\mathrm{STZ})_{2}\right.$ (bipy)] & \begin{tabular}{|c|} 
E. coli: $0.84 \mathrm{mmol} / \mathrm{L}$ \\
P. aeruginosa: $0.10 \mathrm{mmol} / \mathrm{L}$
\end{tabular} & $\begin{array}{l}\text { Complex inactive against Gram } \\
\text { positive bacteria. The free } \\
\text { sulfonamide does not present } \\
\text { inhibitory activity under the tested } \\
\text { concentrations and conditions. }\end{array}$ & {$[7]$} \\
\hline
\end{tabular}


FARMACIA, 2019, Vol. 67, 5

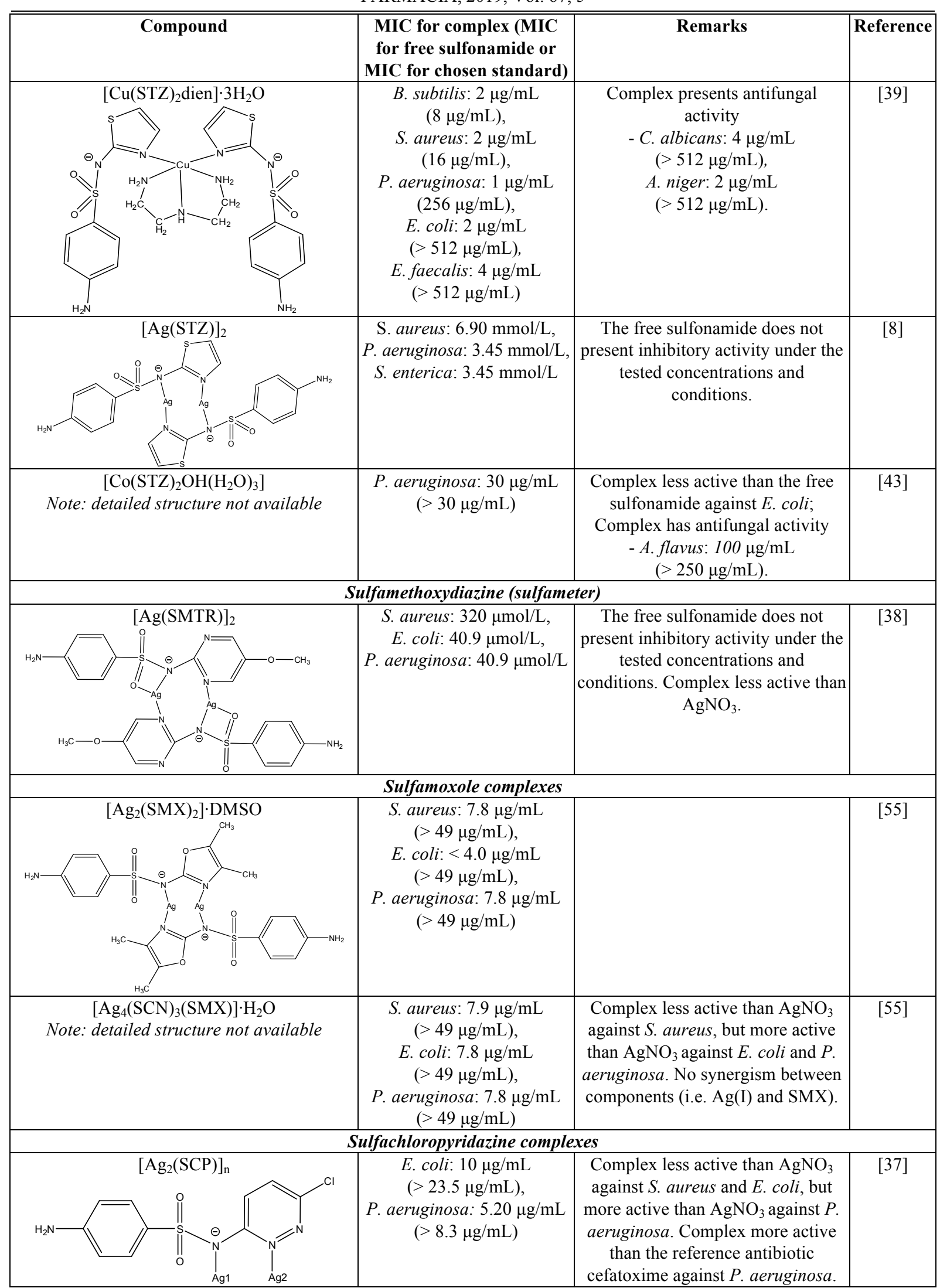

*MIC - minimum inhibitory concentration

*All chemical names and abbreviations for complexes and units for MIC are in accordance with the corresponding references $\mathrm{LH}$ - sulfadiazine; Erx - enrofloxacin; $\mathrm{PPh}_{3}$ - triphenylphosphine; MRSA - methicillin resistant S. aureus; $\mathrm{PPh}_{2}-$ diphenylphosphine; $^{2}$ SMZ - sulfamethizole; phen - 1,10-phenantroline; SMTZ - sulfamethoxazole; STZ - sulfathiazole; bipy - 2,2'-bipyridine; dien - diethylenetriamine; SMTR - sulfamethoxydiazine (sulfameter); SMX - sulfamoxole; DMSO - dimethyl sulfoxide; $\mathrm{SCN}^{-}$- thiocyanate; SCP - sulfachloropyridazine 


\section{Conclusions}

Metal-ion coordination is a promising tool in the development of diverse new antimicrobial agents. Numerous reported metal complexes of sulfonamides exhibit an antibacterial activity higher than that of the free parent sulfonamide which turns them into good candidates for future pharmaceutical research. The antibacterial activity of distinct reported metal complexes of therapeutic sulfonamides is presumably due to one of the following: (i) the metal ion that is slowly released from its complex with the sulfonamide, (ii) the sulfonamide that overcomes cell penetration problems when coordinated with a metal ion, (iii) a synergism of action between the sulfonamide and the metal ion, or (iv) the new active species resulting from the coordination process.

The data currently available in the literature concerning the metal complexes of sulfonamides with known therapeutic value represent however only the proof of concept on the improvement of the antibacterial activity upon metal ion coordination. Detailed mechanistic studies are scarce and further research is required to shed light on aspects such as identification of the bioactive entity, synergistic action of metal ions and free ligands, and a reliable structure-activity relationship. Moreover, literature lacks in well documented studies on the type of mechanism of action that results in an antibacterial effect, e.g. enzyme-like activity (nuclease or superoxide dismutase - like activity), or enzymatic inhibition (inhibition of proteases or carbonic anhydrases). Further studies are therefore required for the design of complexes characterized by selectivity of action, ability to interact with specific targets within the bacterial cell and to disrupt the biochemical pathways involved in drug-resistance, and optimal pharmacokinetic profile.

\section{References}

1. Agertt VA, Cordenonsi Bonez P, Guidolin Rossi G, da Costa Flores V, dos Santos Siqueira F, Rigon Mizdal C, Lorenço Marques L, Manzoni de Oliveira GN, Anraku de Campos MM, Identification of antimicrobial activity among new sulfonamide metal complexes for combating rapidly growing mycobacteria. Biometals, 2016; 29(5): 807-816.

2. Agertt VA, Lorenço Marques L, Cordenonsi Bonez P, Vendruscolo Dalmolin T, Manzoni de Oliveira GN, Anraku de Campos MM, Evaluation of antimycobacterial activity of a sulphonamide derivative. Tuberculosis, 2013; 93(3): 318-321.

3. Anacona J, Osorio I, Synthesis and antibacterial activity of copper(II) complexes with sulphathiazole and cephalosporin ligands. Trans Met Chem., 2008; 33(4): 517-521.

4. Beloso I, Castro J, Garcia-Vasquez J, Perez-Lourido $\mathrm{P}$, Romero J, Sousa A, Different coordinative $(\mathrm{N}, \mathrm{N})$ and $(\mathrm{N}, \mathrm{O})$ bidentate behaviour of N-2-pyridyl-sulfonamides. Electrochemical synthesis and characterization of cadmium(II) complexes. Zeitschrift für Anorganische und Allgemeine Chemie, 2003; 629(2): 275-284.

5. Blasco F, Ortiz R, Perelló L, Borrás J, Amigo J, Debaerdemaeker T, Synthesis and spectroscopy studies of copper(II) nitrate of sulfacetamide drug. Crystal structure of $\left[\mathrm{Cu}(\text { sulfacetamide })_{2}\left(\mathrm{NO}_{3}\right)_{2}\right]$. Antibacterial studies. J Inorg Biochem., 1994; 53(2): 117-126.

6. Bodoki A, Hangan A, Oprean L, Borras J, Castineiras A, Bojita M, DNA-binding study and nuclease activity induced by a copper(II), N,N'-bis[(4-methylphenyl) sulfonyl]ethylenediamine and 1,10-phenantroline ternary system. Farmacia, 2008; 56(6): 607-614.

7. Bormio Nunes JH, de Paiva REF, Cuin A, da Costa Ferreira AM, Lustri WR, Synthesis, spectroscopic characterization, crystallographic studies and antibacterial assays of new copper(II) complexes with sulfathiazole and nimesulide. J Mol Struct., 2016; 1112: 14-20.

8. Bormio Nunes JH, de Paiva REF, Cuin A, Lustri WR, Corbi PP, Silver complexes with sulfathiazole and sulfamethoxazole: Synthesis, spectroscopic characterization, crystal structure and antibacterial assays. Polyhedron, 2015; 85: 437-444.

9. Borthagaray G, Mondelli M, Torre MH, Essential transition metal ion complexation as a strategy to improve the antimicrobial activity of organic drugs. J Infec Dis Epidemiol., 2016; 2(2): 1-8.

10. Boughougal A, Cherchali FZ, Messai A, Attik N, Decoret D, Hologne M, Sanglar C, Pilet G, Tommasino JB, Luneau D, A new model of metalloantibiotic: synthesis, structure and biological activity of a zinc(II) mononuclear complex carrying two enrofloxacin and sulfadiazine antibiotics. New J Chem., 2018; 42(18): 15346-15352.

11. Casanova J, Alzuet G, Borrás J, Amigó JM, Coordination behaviour of sulfathiazole. Crystal structure of dichloro disulfathiazole methanol $\mathrm{Cu}(\mathrm{II})$ complex. Zeitschrift für Kristallographie - Crystalline Materials. 1994; 209(3): 271-273.

12. Casanova J, Alzuet G, Borrás J, Carugo O, Crystal structures and superoxide dismutase mimetic activity of $\left[\mathrm{CuL}_{2}(\mathrm{Him})_{2}\right] \cdot \mathrm{MeOH}$ and $\left[\mathrm{CuL}_{2}(\mathrm{mim})_{2}\right] \cdot \mathrm{H}_{2} \mathrm{O}[\mathrm{HL}=$ 4-amino-N-(thiazol-2-yl)benzenesulfonamide, $\mathrm{Him}=$ imidazole, $\operatorname{mim}=\mathrm{N}$-methylimidazole]. $J$ Chem Soc, Dalton Trans., 1996; 11: 2239-2244.

13. Casanova J, Alzuet G, Borrás J, Timoneda J, GarcíaGranda S, Cándano-González I, Coordination behavior of sulfathiazole. Crystal structure of dichloro-disulfathiazole ethanol $\mathrm{Cu}$ (II) complex. Superoxide dismutase activity. J Inorg Biochem., 1994; 56(2): 65-76.

14. Casanova J, Alzuet G, Ferrer S, Borrás J, GarcíaGranda S, Perez-Carreño E, Metal complexes of sulfanilamide derivatives. Crystal structure of [Zn(sulfathiazole $\left.)_{2}\right] \cdot \mathrm{H}_{2} \mathrm{O}$. J Inorg Biochem., 1993; 51(4): 689-699.

15. Casanova J, Alzuet G, Latorre J, Borrás J, Spectroscopic, magnetic, and electrochemical studies of a dimeric Nsubstituted-sulfanilamide copper(II) complex. X-ray and molecular structure of the $\mathrm{Cu}_{2}$ (sulfathiazolato) complex. Inorg Chem., 1997; 36(10): 2052-2058.

16. Chohan ZH, Shad HA, Youssoufi MH, Ben Hadda T, Some new biologically active metal-based sulfonamide. Eur J Medicin Chem., 2010; 45(7): 2893-2901.

17. Chopra I, The increasing use of silver-based products as antimicrobial agents: a useful development or a 
FARMACIA, 2019, Vol. 67, 5

cause for concern? J Antimicrob Chemother., 2007; 59(4): 587-590.

18. Costerton J, Lewandowski Z, Caldwell D, Korber D, Lappin-Scott H, Microbial biofilms. Annu Rev Microbiol., 1995; 49: 711-745.

19. de Paiva REF, Abbehausen C, Gomes AF, Gozzo FC, Lustri WR, Formiga ALB, Corbi PP, Synthesis, spectroscopic characterization, DFT studies and antibacterial assays of a novel silver(I) complex with the anti-inflammatory nimesulide. Polyhedron, 2012; 36(1): 112-119.

20. Desbouis D, Troitsky IP, Belousoff MJ, Spiccia L, Graham B, Copper(II), zinc(II) and nickel(II) complexes as nuclease mimetics. Coord Chem Rev., 2012; 256: 897-937.

21. Di Santo A, Gil DM, Pomiro F, Piro OE, Echeverría GA, Arena M, Luciardi C, Carbonio RE, Altabef AB, Biofilm inhibition by a new Mn(II) complex with sulfamethoxazole: Synthesis, spectroscopic characterization and crystal structure. Inorganica Chimica Acta, 2015; 436: $16-22$

22. Fiori ATM, Nakahata DH, Cuin A, Lustri WR, Corbi $\mathrm{PP}$, Synthesis, crystallographic studies, high resolution mass spectrometric analyses and antibacterial assays of silver(I) complexes with sulfisoxazole and sulfadimethoxine. Polyhedron, 2017; 121: 172-179.

23. Fox CL, Modak SM, Mechanism of Silver Sulfadiazine Action on Burn Wound Infections. Antimicrob Agents Chemother., 1974; 5(6): 582-588.

24. Foye WO, Lemke TL, Williams DA, Principle of Medicinal Chemistry. $4^{\text {th }}$ ed: Williams \& Williams; 1995; 709-713.

25. Fraser JF, Bodman J, Sturgess R, Faoagali J, Kimble $\mathrm{RM}$, An in vitro study of the anti-microbial efficacy of a $1 \%$ silver sulphadiazine and $0.2 \%$ chlorhexidine digluconate cream, $1 \%$ silver sulphadiazine cream and a silver coated dressing. Burns, 2004; 30(1): 35-41.

26. Gelband H, Miller-Petrie M, Pant S, Gandra S, Barter D, White A, Laxminarayan R, The State of the World's Antibiotics, 2015; The Center For Disease Dynamics, Economics \& Policy, 2015.

27. Gringauz A, Introduction to Medicinal Chemistry. Wiley-UCH, New-York; 1997; 61-67.

28. Hangan A, Bodoki A, Oprean L, Crisan O, Mihalca I, Synthesis of new N-substituted heterocyclic sulfonamides. Farmacia, 2012; 60(6): 932-938.

29. Hangan AC, Stan RL, Sevastre B, Gheorghe-Cetean S, Oprean L, DNA cleavage study and SOD-mimetic activity of a new $\mathrm{Cu}$ (II) complex. Farmacia, 2017; 65(3): 368-373.

30. Kremer E, Facchin G, Estévez E, Alborés P, Baran EJ, Ellena J, Torre MH, Copper complexes with heterocyclic sulfonamides: Synthesis, spectroscopic characterization, microbiological and SOD-like activities: Crystal structure of $\left.[\mathrm{Cu} \text { (sulfisoxazole })_{2}\left(\mathrm{H}_{2} \mathrm{O}\right)_{4}\right] \cdot 2 \mathrm{H}_{2} \mathrm{O}$. $J$ Inorg Biochem., 2006; 100(7): 1167-1175.

31. Lemire JA, Harrison JJ, Turner RJ, Antimicrobial activity of metals: mechanisms, molecular targets and applications. Nat Rev Microb., 2013; 11: 371-384.

32. Mansour AM, Coordination behavior of sulfamethazine drug towards Ru(III) and Pt(II) ions: Synthesis, spectral, DFT, magnetic, electrochemical and biological activity studies. Inorganica Chimica Acta, 2013; 394: 436-445.
33. Marques LL, Manzoni de Oliveira G, Schulz Lang E, Anraku de Campos MM, Soccol Gris LR, New gold(I) and silver(I) complexes of sulfamethoxazole: Synthesis, $\mathrm{X}$-ray structural characterization and microbiological activities of triphenylphosphine(sulfamethoxazolatoN2)gold(I) and (sulfamethoxazolato)silver(I). Inorg Chem Communic., 2007; 10(9): 1083-1087.

34. Mizdal CR, Stefanello ST, da Costa Flores V, Agertt VA, Bonez PC, Rossi GG, da Silva TC, Antunes Soares FA, de Lourenço Marques L, de Campos MMA, The antibacterial and anti-biofilm activity of goldcomplexed sulfonamides against methicillin-resistant Staphylococcus aureus. Microb Pathol., 2018; 123: 440-448.

35. Mizdal CR, Stefanello ST, Nogara PA, Antunes Soares FA, de Lourenço Marques L, de Campos MMA, Molecular docking, and anti-biofilm activity of goldcomplexed sulfonamides on Pseudomonas aeruginosa. Microb Pathog., 2018; 125: 393-400.

36. Mondelli M, Bruné V, Borthagaray G, Ellena J, Nascimento OR, Leite CQ, Batista AA, Torre MH, New Ni(II)-sulfonamide complexes: Synthesis, structural characterization and antibacterial properties. X-ray diffraction of $\left[\mathrm{Ni}(\text { sulfisoxazole })_{2}\left(\mathrm{H}_{2} \mathrm{O}\right)_{4}\right] \cdot 2 \mathrm{H}_{2} \mathrm{O}$ and [Ni(sulfapyridine) $)_{2}$. J Inorg Biochem., 2008; 102(2): 285-292.

37. Mosconi N, Giulidori C, Velluti F, Hure E, Postigo A, Borthagaray G, Back DF, Torre MH, Rizzotto M, Antibacterial, antifungal, phytotoxic, and genotoxic properties of two complexes of $\mathrm{Ag}^{\mathrm{I}}$ with sulfachloropyridazine (SCP): X-ray diffraction of $[\mathrm{Ag}(\mathrm{SCP})] \mathrm{n}$. Chem Med Chem., 2014; 9(6): 1211-1220.

38. Nakahata DH, Lustri WR, Cuin A, Corbi PP, Crystal structure, spectroscopic characterization and antibacterial activities of a silver complex with sulfameter. $J \mathrm{Mol}$ Struct., 2016; 1125: 609-615.

39. Öztürk F, Bulut İ, Bekiroğlu Y, Bulut A, Spectroscopic, structural, electrochemical and antimicrobiological studies of $\mathrm{Cu}(\mathrm{II})$-sulfathiazole complex with diethylenetriamine ligand. Polyhedron, 2016; 119: 420-428.

40. Pascual-Álvarez A, Topală T, Estevan F, Sanz F, AlzuetPiña $G$, Photoinduced and self-activated nuclease activity of copper(II) complexes with $\mathrm{N}$-(quinolin-8yl)quinolin-8-sulfonamide - DNA and bovine serum albumin binding. Eur J Inorg Chem., 2016; 2016(7): 982-994.

41. Pasquale TR, Tan JS, Nonantimicrobial effects of antibacterial agents. Clin Infect Dis., 2005; 40(1): 127-135.

42. Pessoa Rocha D, Ferreira Pinto G, Ruggiero R, de Oliveira CA, Guerra W, Soares Fontes AP, Teixeira Tavares T, Marques Marzano I, Pereira-Maia EC, Coordenação de metais a antibióticos como uma estratégia de combate à resistência bacteriana. Química Nova, 2011; 34: 111-118,

43. Pontoriero A, Mosconi N, Monti L, Bellú S, Williams PAM, Raimondi M, Lima B, Feresin GE, Nerli B, Rizzotto M, Synthesis, characterization and biological studies of a cobalt(III) complex of sulfathiazole. Chem Biol Interact., 2017; 278: 152-161.

44. Ramadan AM, Structural and biological aspects of copper (II) complexes with 2-methyl-3-amino-(3H)quinazolin-4-one. J Inorg Biochem., 1997; 65(3): 183189. 
45. Raman N, Muthuraj V, Ravichandran S, Kulandaisamy A, Synthesis, characterisation and electrochemical behaviour of $\mathrm{Cu}$ (II), $\mathrm{Co}$ (II), $\mathrm{Ni}$ (II) and $\mathrm{Zn}$ (II) complexes derived from acetylacetone and p-anisidine and their antimicrobial activity. Proc Ind Acad Sci (Chem Sci.), 2003; 115(3): 161-167.

46. Rocha M, Piro OE, Echeverría GA, Pastoriza AC, Sgariglia MA, Soberón JR, Gil DM, Co(II), Ni(II) and $\mathrm{Cu}(\mathrm{II})$ ternary complexes with sulfadiazine and dimethylformamide: Synthesis, spectroscopic characterization, crystallographic study and antibacterial activity. $\mathrm{J} \mathrm{Mol}$ Struct., 2019; 1176: 605-613.

47. Ronconi L, Sadler PJ, Using coordination chemistry to design new medicines. Coord Chem Rev., 2007; 251(13): 1633-1648.

48. Stewart PS, Costerton WJ, Antibiotic resistance of bacteria in biofilms. The Lancet, 2001; 358(9276): 135-138.

49. Tačić A, Nikolić V, Nikolić L, Savić I, Antimicrobial sulfonamide drugs. Adv Tech., 2017; 6(1): 58-71.

50. Tiperciuc B, Oniga O, Moldovan C, Chimie Pharmaceutique, Antiseptiques-Desinfectants. Chimiotherapiques generales. Antiparasitaires. Cluj-Napoca: Editura Todesco; 2009; 116-117.

51. Tommasino JB, Renaud FNR, Luneau D, Pilet G, Multi-biofunctional complexes combining antiseptic copper(II) with antibiotic sulfonamide ligands: Structural, redox and antibacterial study. Polyhedron, 2011; 30(10): 1663-1670.

52. Topală T, Bodoki A, Pascual-Álvarez A, Oprean L, Oprean R, Design, synthesis and characterization of new $\mathrm{Cu}(\mathrm{II})$ complexes with $\mathrm{N}$-substituted sulfonamide ligands. Studia UBB Chemia, 2014; 59(1): 187-200.

53. Turner RJ, Metal-based antimicrobial strategies. Microb Biotech., 2017; 10(5): 1062-1065.

54. Uivarosi $\mathrm{V}$, Metal complexes of quinolone antibiotics and their applications: an update. Molecules, 2013; 18(9): 11153-11197.

55. Velluti F, Mosconi N, Acevedo A, Borthagaray G, Castiglioni J, Faccio R, Back DF, Moyna G, Rizzotto $\mathrm{M}$, Torre MH, Synthesis, characterization, microbiological evaluation, genotoxicity and synergism tests of new nano silver complexes with sulfamoxole: X-ray diffraction of $\left[\mathrm{Ag}_{2}(\mathrm{SMX})_{2}\right] \cdot$ DMSO. J Inorg Biochem., 2014; 141: 58-69.

56. Wolff ME, Burger's Medicinal Chemistry and Drug Discovery, Vol 2, $5^{\text {th }}$ ed. Wiley, Santa Barbara; 1996; 528-576.

57. Yamamoto LM, Nunes JHB, Ribeiro MA, Ferreira AMC, Lustri WR, Corbi PP, Copper(II) and silver(I) complexes with sulfamethizole: synthesis, spectroscopic characterization, ESI-QTOF mass spectrometric analysis, crystal structure and antibacterial activities. Polyhedron, 2017; 138: 168-176.

58. Zhang P, Sadler PJ, Redox-active metal complexes for anticancer therapy. Eur J Inorg Chem., 2017; 2017(12): 1541-1548.

59. Zhou CH, Gan LL, Zhang YY, Zhang FF, Wang GZ, Jin L, Geng RX, Review on supermolecules as chemical drugs. Sci Chi Ser B: Chem., 2009; 52(4): 415-458. 